\title{
Bakteriyal Inokulantların Sorgum Silajlarının Fermantasyon, Aerobik Stabilite ve Rumen Parçalanabilirlik Özellikleri Üzerine Etkileri
}

\author{
Ismail FILYA ${ }^{1}$
}

\author{
Ali KARABULUT ${ }^{+}$
}

Hatice KALKAN'

Ekin SUCU ${ }^{1}$

Geliş Tarihi : 01,02.2001

\begin{abstract}
Özet: Bu çalışma silaj katkı maddesi olarak kullanılan bakteriyal inckulantların, farklı dönemlerde hasat edilerek yapılan sorgum (Sorghum bicolor) silajlarinın fermantasyon, aerobik stabilite ve rumen parçalanabilirilk ozzellikleri üzerindeki etkilerinin saptanması amacı ile düzenlenmiștir. Araștırmada kullanilan sorgum, çiçeklenme ve sût olum dönemlerinde hasat edilmiştir. Bakteriyal inokulant olarak ise Inokulant 1188 (Pioneer(B, USA) ve Sil-All (Alteck, UK) kullanılmıștır. Inokulantlar silajlara $10^{6} \mathrm{cfu} \mathrm{g}^{-1}$ dQzeyinde katılmıșlardir. Sorgumlar yainızca gaz çıkıșına olanak tanıyan, 1.5 litrelik özel cam kavanozlara silolanmıșlardır. Kavanozlar laboratuvar koşullarında $18 \pm 2{ }^{\circ} \mathrm{C}$ ' de depolanmıșlardir. Silolamadan sonraki $2,4,7,15$ ve 60 . günlerde her gruptan $3^{\prime}$ er kavanoz açılarak silajlarda kimyasal ve mikrobiyolojik analizler yapıımıştır. Silolama döneminin sonunda (60. gün) açılan tüm silajlar 5 gün süre ile aerobik stabilite testine tabi tutulmuşlardir. Ayrica bu silajlarin, rumen kuru ve organik madde parçalanabilirlikleri saptanmıștır. Sonuç olarak bakteriyal inokulantların sorgum silajlarının fermantasyon özelliklerini olumlu yönde etkilediği, silajların aerobik stabilite ile rumen kuru ve organik madde parçalanabilirliklerini ise etkilemediği saptanmıştır. Sorgumun olgunlașmasına bağı olarak silajların aerobik stabiliteleri dūşerken, rumen kuru ve organik madde parçalanabilirlikleri ise artmıştir.
\end{abstract}

Anahtar Kelimeler; Bakteriyal inokulantlar, sorgum, silaj, fermantasyon, aerobik stabilite, rumen parçalanabilirliği

\section{The Effects of Bacterial Inoculants on the Fermentation, Aerobic Stability and Rumen Degradability of Sorghum Silages}

\begin{abstract}
This research was carried out to determine the effect of bacterial inoculants using as silage additives on the fermentation, aerobic stability and rumen degradability of harvested and ensiled sorghum (Sorghum bicolor) at different stages of maturity. Sorghum was harvested at flowering and milk dough stages. Inoculant 1188 (Pioneer(8), USA) and Sil-All (Alteck, UK) were used as bacterial inoculants. Inoculants were applied to silages $10^{6}$ cfu $\mathrm{g}^{-1}$ levels. Sorghums were ensiled in 1.5 liter special glass jars equipped with a lid that enables gas release only. The jars were stored at $18 \pm 2{ }^{\circ} \mathrm{C}$ at laboratory conditions. Three jars from each group were sampled for chemical and microbiological analyses on the days 2, 4, 7, 15 and 60 after ensiling. All silages were opened at the end of the ensiling period (60 days) and subjected to an aerobic stability test for 5 days. In addition rumen dry and organic matters degradabilities of the silages were determined. As a result, bacterial inoculants improved fermentation characteristics of sorghum silages. However, inoculants did not improve aerobic stability and rumen dry and organic matters degradabilities of sorghum silages. Depend on maturity of sorghum, aerobic stability impaired and rumen dry and organic matters degradability of the silages were increased.
\end{abstract}

Key Words: Bacterial inoculants, sorghum, silage, fermentation, aerobic stability, rumen degradability

\section{Giriş}

Silaj, genellikle su içeriği \% $50^{\prime}$ nin üzerinde olan yeşil yem, bitkisel ürün, tarımsal artık ve atıkların doğal fermantasyonu sonucu elde edilen bir yem kaynağıdır (Filya, 2000, a). Silolama olayında temel olarak; laktik asit bakterileri (LAB) anaerobik koşullar altında suda eriyebilir karbonhidratları (SEK) başta laktik asit olmảk uzere organik asitiere dönusștürürler. Bunun sonucunda ise $\mathrm{pH}$ dūşer ve su içeriği yüksek materyal, bozulmaya neden olan mikroorganizmalardan korunmuş olur (Filya ve ark., 2000).
Silaj fermantasyonunda kullanılmak uzere çok sayıda kimyasal ve biyolojik katkı maddesi geliştirilmiştir. Özellikle biyolojik kökenli katkı maddeleri; kullanımiarının oldukça kolay olması, gưvenli oluşları, toksik etkilerinin olmayışı, silaj yapımında kullanilan makinelerde korozyona sebep olmamaları, çevre kirliliği yaratmamaları ve sonuç olarak doğal ürünler olmaları gibi önemli avantajlara sahip oldukları içín kimyasal kökenli katkı maddelerine göre daha fazla tercih edilmektedirler (Filya ve ark., 2000).

\footnotetext{
${ }^{1}$ Uludağ Óniv. Ziraat Fak. Zootekni Bölümü- Bursa
} 
FILYA, I. A. KARABULUT, H. KALKAN ve E, sUCU, "Bakteriyal inokulantlarin sorgum silajlarinin fermantasyon, aerobik stabilite ve rumen parçalanabilintik özellikler uzerine etkileri"

En onemli biyolojik katk maddeleri bakteriyal inokulantlardır. Silaj fermantasyonunda kullanılmak ozere çeşitti bizelliklerde bir çok bakteriyal inokulant geliştirilmiştir. Bu inokulantlar genellikle Lactobacillus. Pediococcus ve Enterococcus cinsi mikroorganizmaları içerirler. Ancak bakteriyal inokulantların bäyōk bir cogunlugu başta Lactobacillus plantarum olmak ozere homofermantatif ozellikteki LAB' dirler. Bu tür mikroorganizmalar şekerleri ağırliklı olarak laktik aside fermente ederler (Woolford, 1984; McDonald ve ark., 1991). Cessitti bitkilerin silolanmasinda $L A B$ inokulantlarinin kullanımı ile ilgili olarak yapılan bir çok çalışmada bu katkı maddelerinin silajların $\mathrm{pH}^{\prime}$ sinı doşurdoğo, laktik asit ve laktik:asetik asit oranin artırdıği, asetik asit ve amonyakazotu duzeyini daşüdoğa saptanmıștı (Lindgren ve ark. 1983; Weinberg ve ark., 1988; Henderson ve ark., 1990; Filya ve ark., 1999), Bunun yanı sıra LAB inokulantlarinin silajlarin aerobik stabiliteleri (silo omro) Ozerindeki etkilerinin incelendiği araştırma sonuçlarında, bazı araștirıcilar $\angle A B$ inokulantlarınin silajların aerobik stabilitesini artırdığını bildirirlerken (Ohyama ve ark., 1975; Pahlow, 1982; Holzer ve ark, 1999), bazi araştıncilar ise etkilemediğini, silajlarda guzle gorolor bir koflenme ve yoğun bir karbondioksit gazi $\left(\mathrm{CO}_{2}\right)$ üretimi olduğuno bildirmișlerdir (Kennedy, 1990; Weinberg ve ark, 1993, $a, b$; Filya ve ark., 2000). Ancak ozellikle kuru madde (KM) ve SEK içeriği yeterli olan orünlerde LAB inokulantlan, silajlanı gerek fermantasyon özellikJerini gerekse aerobik stabilitelerini olumlu yönde etkileyebilmektedirler (Seale, 1986; Davies and Hall, 1999; Filya ve ark., 2000).

Bakteriyal inokulantlar genel olarak ruminantların performansları azerinde az da olsa bir artiş sağlamaktadırlar (Harrison, 1989; Bolsen ve ark., 1992 a; Muck, 1993). Silaj katkı maddesi olarak kullanilan bakteriyal inokulantlar silajların KM sindirilebilirliğini artınilar. KM sindirilebilirliğinde meydana gelen bu artıs da ruminantların performanslarını olumlu yőnde ekilemektedir (Bolsen ve ark., 1992 b; Rooke and Kafilzadeh, 1994; Filya, 2000 b,).

Son yıllarda alkemizde ekim alani genişleyen ve bzellikle silajlık olarak ekilen sorgumun besleme degeri, hasat zamaninin gecikmesine bağli olarak bayôk oranda duşebilmektedir. Ozellikle bitki olgunlaştıkça bitkinin Içerdiği lignin ve hemisellaloz gibi bitki hocre duvanni alușturan bir kısım bileşiklerin arasındaki bağlar bazı sorgum çeşitterinin sindirilme derecesini duşarmektedir (Goto ve ark., 1991). Bu nedenle sorgumun tam olgunlaşmadan ônce, danelerin çiçeklenme veya süt alum donemlerinde biçilmeleri çok önemli bir konu olup, bu donemlerin geçirimesi halinde sorgum silajinın besleme değeri boyak ólçude daşmektedir (Black ve ark., 1980; Donnhauser ve ark., 1990).

Bu çalışmada, ozellikle älkemizde son birkaç yildir kullanılmaya başlayan bir silaj katkı maddesi olan bakteriyal inokulantlarin, yine olkemizde son yillarda silajlık olarak ekilmeye başlayan sorgumdan yapilan silajlann: fermantasyon özellikleri, aerobik stabiliteleri ve rumen parçalanabilirlikjeri ozerindeki etkileri saptanmaya çalışımıștır.

\section{Materyal ve Yöntem}

\section{Silaj ve hayvan materyali}

Araștımada silaj materyali olarak Uludaç Unniversitesi Ziraat Fakultesi Araștimna ve Uygulama Merkezi' nde yetiştirilen sorgum (Sorghum bicalor) kullanılmiştır. Silajiarın rumen parçalanabilirlik ozelliklerinin saptanmasında ise rumen kanulo takılı 3 baş Merinos erkek tokiu kullanilmıştır.

\section{Silajlann hazirlanması}

Silaji yapilacak olan sorgumlar, çiçeklenme ve süt olum devrelerinde olmak izere ikj farkli dönemde hasat odilmiș ve daha sonra parçalama makinesinde yaklașık $1.5 \mathrm{~cm}$ uzunluğunda parçalanmışlardır. Parçalanan materyaller 1.5 litre kapasiteli ve yalnızca gaz çıkıșina olanak taniyan cam kavanozlara $3^{\prime}$ er paralelli olarak sillolanmışlardir. Araștımmada $45^{\circ} \mathrm{I}$ çiçeklenme, $45^{\prime} \mathrm{i}$ sut olum donnemindeki sorgum materyallerine ait toplam 90 kavanoz silaj yapılmıştır. Kavanozlar laboratuvar ortaminda $18 \pm 2{ }^{\circ} \mathrm{C}$ sicaklıkta tutuimusșlardir. Her muamele grubundan $3^{\prime}$ er kavanoz silolandiktan sonraki $2,4,7,15$ ve 60 , gunlerde açlarak kimyasal ve mikrobiyolojik arializlere tabi tưtulmuştur. Son silajların açıldığı araștımanın 60. günönde tüm silajlara 6 gün süre lle Ashbell ve ark. (1991) tarafından geliştirilen aerobik stabilite testi uygulanmiştir.

\section{Kullanilan bakteriyal inokulantlat}

1. Inokulum A. Inokulant 1188 (Ploneer@, USA). Oretici firmanın bildirdiğine göre, Lactobacillus plantarum ve Enterococcus faecium içermekte olup (sırasıyla \% 80 ve \% 20 dozeyinde), Rogosa agar uzerinde sayilan mikroorganizma sayısı $3.0 \times 10^{10} \mathrm{~g}^{-11} \mathrm{dır}$

2. Inokulum B. Sil-All (Aliteck, UK). Oretici firmanin bildirdiğine göre, bakteri-enzim karışıml olup Streptococcus faecium, Lactobacillus plantarum ve Pediococcus acidilactici bakterileri ile sellulaz, hemisellülaz ve amilaz enzimlerini içemektedir (ürunán içerdiği mikroorganizma sayısı Oretici firma tarafindan belirtilmerniştir)

Inokulantlar üretici firmalann onerdiḡi oraniarda kullanilmıştır. Buna gore;

1. grup kontrol grubu olup katki maddesi içermemektedir.

2. grupta Inokulant 1188 (Pioneer@, USA) kullanilmiștir. Çiçeklenme döneminde hasat edilmiş, $10 \mathrm{~kg}$ parçalanmış taze sorgum $1 \times 4 \mathrm{~m}$ temiz bir alana yayıimiştir. Soz konusu inokulanttan $330 \mathrm{mg}$ alınarak 20 ml çeşme suyu lçerisinde çôzulmûş ve materyal üzerine homojen bir şekilde püskürtölmûşturr. Böylece materyale $10^{6}$ koloniform anite (cfu) $\mathrm{g}^{-1}$ inokulant katilmıştır. 
3. grupta Sil-All (Ailteck, UK) kullanilmiştir. Çiçeklenme döneminde hasat edilmiş, $10 \mathrm{~kg}$ parçalanmiş taze sorgum $1 \times 4 \mathrm{~m}$ temiz bir alana yayılmiștır. Soz konusu inokulanttan $0.1 \mathrm{~g}$ alınarak $20 \mathrm{ml}$ çeşme suyu içerisinde çözülmuş ve materyal uzerine homojen bir sekilde püskurtulmuiştur. Böylece materyale $10^{6} \mathrm{cfu}^{-1}$ inokulant katilmıstır.

Yukarida çiçeklenme doneminde hasat edilen taze materyale uygulanan işlemlerin aynilari sôt olum doneminde hasat edilen taze materyale de uygulanmıştır.

\section{Kimyasal ve mikrobiyolojik analizler}

Araştırmada kullanılan taze ve silolanmış sorgum materyallerinin ham besin maddeleri içerikleri Weende analiz yöntemi; silajların laktik, asetik ve butrik asit Içerikleri Lepper yơntemi ile saptanmiştir (Akyildiz, 1984). Silajlarin SEK içeriklerinin saptanmasında Dubois ve ark. (1956) tarafindan bildirilen fenol sulforik asit yơntemi; etanol içeriklerinin saptanmasında Anonim (1983); natr deterjanda çózanmeyen lif (NDF), asit deterjanda çözunmeyen lif (ADF) ve asit deterjanda çözünmeyen lignin (ADL) içeriklerinin saptanmasinda ise Van Soest (1982) tarafindan geliştirilen analiz yôntemleri kullanilmiştır.

Araştırmada taze ōrnek ve silajiarın içerdiği lactobacilli, maya ve kuf gibi mikrobiyal populasyonlar Filya ve ark., (2000) tarafindan tanımlanan mikrobiyolojik analiz youtemlerine göre; enterobacteria, Weinberg ve ark., (1983 b), clostridia ise Spoelstra (1984) tarafindan tanimlanan yönternlere göre belirlenmiştir.

\section{Rumen parçalanabilirlik ôzellikleri}

Araştırmanin son günú olan 60 . günde açılan silajların rumende parçalanabilirlik ózellikleri Mehrez ve Ørskov (1977) tarafından bildirilen naylon torba yontemi lle saptanmıştir, Silajlann rumende parçalanabilinlik ozellikieri Ørskov ve McDonald (1979) tarafindan geliştirilen $p=a+b$ $\left(1-e^{-c h}\right)$ eksponensiyel denklemine göre Neway bilgisayar programindan yaralanilarak saptanmıştır.

Diğer yandan araștırmada çiçeklenme dönemindeki sorgumun hücre duvarı kapsamı (NDF, ADF ve ADL) sọt olum donemindeki sorgumun hücre duvarı kapsamindan daha yoksek bulunmuştur. Oysa bilindiği gibi bitkilerin algunlaşmasına bağlı olarak hücre duvarı kapsamlan artmaktadir. Ancak ozellikle dane verimi yoksek olan sorgum çeșitlerinde bitkinin olgunlaşmasiyla birlikte bitkinin nişasta içeriği artmakta ve böylece sorgumun hücre duvarı kapsami oransal olarak azalmaktadir (Owen ve Webster, 1963; Hart, 1990; Meeske ve ark., 1993).

\section{Istatistik analizler}

Araştırmadan elde edilen verilerin istatistiki olarak değerlendirilmesinde varyans analizi, ortalamalar arasında göblen farkłliklann onem seviyesinin kontrol edilmesinde ise Duncan çoklu karșılaştırma testinden yararlanılmıştır (SAS, 1988).

\section{Bulgular ve Tartışma}

Taze ve silolanmış sorgumlara ait kimyasal analiz sonuçlan Çizelge 1 'de verilmiştir.

Çizelge 1 ' de de gôräldago gibi gerek çiçeklenme gerekse süt olum dönemlerinde hasat edilen sorgumların en belirgin ozellikleri SEK ve ham protein içeriklerinin yäksek olmasıdır, Bunun da nedeni, bitkinin olgunlaşmaya başlamasi ile birlikte danelerin içerdiği şekerlerin nişastaya dönüşmesidir. Çizelge 1' de verilen sorgum silajlarına ait kimyasal analiz sonuçları incelendiğinde, silolamanın ilk gönlerinden itibaren çok hizlı bir fermantasyon gerçekleştıği görülmektedir. Nitekim sorgumun içerdiği SEK' in fermantasyonu sonucunda her iki donemde hasat edflarek silolanan bitkilerin $\mathrm{pH}^{\prime}$ ları önemii dozeyde daşmüştur ( $P<0,05)$ Araștırmada kullanilan her iki inokulant da bu daşaşa hizlandırmıştır. Her iki dönemdeki sorgum silajlarinda temel fermantasyon orono laktik asit olmuştur, Araştırmada kullamian her iki inokulant da sorgum silajlarinin laktik asit içeriklerini fermantasyonun 7. gününden itibaren kontrol grubuna göre önemli düzeyde artırmıştır $(P<0.05)$. Bunun yanı sıra $B O$ günlák fermantasyon sonucunda inokulant kullanitan silajlardaki asetik ve bätrik asit dủzeyleri önemli düzeyde daşak bulunmuştur $(P<0,05)$. Bu bulgular uzerinde ozellikle sorgumun silaj fermantasyonu açısından SEK içeriğinin yeteril ve tampon kapasitesinin (asitliğe karşı direnç) doşăk oluşu çok onemli rol oynamaktadir. Bununla bitilkte kullanılan bakteriyal inokulantlar da sorgumun içerdiği yeterli düzeydeki SEK' I Rullanarak yoğun bir şekilde laktik asit äretmiş ve $\mathrm{pH}^{\prime}$ yi da çok hizli bir sekilde duşurmusşlerdir. Taze ve sillolanmış sorgumun kimyasa! analizleri lie ligili olarak araștımadan elde edilen bulgular, çeşitli bitkilerde farklı bakteriyal inokulantların kullanildığı çalışmaların sonuçları ile benzerlik göstermektedir (Lindgren ve ark. 19B3; Weinberg ve ark, 1988; Henderson ve ark, 1990; Filya ve ark. 1999 Bununla birlikte araştırmada kullanılan bakteriyal inokulantlantn, çiçeklenme ve süt olum dönemlerinde hasat edilerek yapilan sorgum silajlarinin hocre duvari kapsami uzerindeki etkileri onemsiz dazeyde bulunmuştur. Inokulant $B$, içerdiği LAB' nin yani sıra ayrıca bitki hücre duvarını parçalayıcı sellolaz ve hemisellulaz enzimlerini de içermesine rağmen, sorgumun hücre duvarı kapsamı Ozerinde önemfl bir azaimaya neden olmamiştir Diğer gruplara göre sorgumun höcre duvan kapsaminda ancak onemsiz duzeyde bir azalma sağlayabilmiștir. Bunun da başlıca nedeni sorgumun yeterli düzeyde SEK içermesidir. Sorgumun hocre duvari kapsami ve inokulantlarin bitkilerin hocre duvari kapsamlari üzerindeki etkileri lie ligili olarak araştırmadan elde edilen bulgular Owen ve Webster (1963), Hart (1990), Meeske ve ark., (1993) ve Muck (1993)' in bulgular ile uyumludur. 
Çizelge 1. Sorgum silajlarına ait kimyasal analiz sonuçları $\left(\bar{x} \pm \mathrm{S} \bar{x} ; \mathrm{KM} \mathrm{M}^{\prime} \mathrm{de}, \%\right)$

\begin{tabular}{|c|c|c|c|c|c|c|c|c|c|c|c|c|c|}
\hline Gün & Uygulama & $\mathrm{pH}$ & KM & SEK & NDF & ADF & ADL & $\mathrm{HK}$ & HP & LA & AA & BA & Etanol \\
\hline & Taze* & & & & & & & & & & & & \\
\hline \multirow[t]{3}{*}{0} & Çiçek d. & $5.4 \pm 0$ & $26 \pm 2$ & $22+2$ & $63 \pm 3$ & $39 \pm 1$ & $6 \pm 0$ & $6 \pm 0$ & $5 \pm 0$ & $1 \pm 0$ & $0.3 \pm 0$ & 0 & 0 \\
\hline & Sat ol d. & $6.1 \pm 1$ & $28 \pm 1$ & $16 \pm 2$ & $60 \pm 3$ & $30 \pm 2$ & $4 \pm 1$ & $7 \pm 0$ & $4 \pm 0$ & $1 \pm 0$ & $0.4 \pm 0$ & 0 & 0 \\
\hline & Çiçeklenme & dönemi & & & & & & & & & & & \\
\hline \multirow[t]{8}{*}{2} & Kontrol & $5.2 \pm 0^{\circ}$ & $27 \pm 2^{2}$ & $17 \pm 2^{\circ}$ & $64 \pm 4^{\prime \prime}$ & $39 \pm 2^{2}$ & $6 \pm 1^{2}$ & $7 \pm 0^{\circ}$ & $5 \pm 0^{a}$ & $1 \pm 0^{\circ}$ & 0 & 0 & 0 \\
\hline & IA & $4.7 \pm 0^{\circ}$ & $26 \pm 2^{a}$ & $18 \pm 2^{2}$ & $63 \pm 4^{2}$ & $38 \pm 2^{\prime \prime}$ & $6 \pm 1^{\circ}$ & $6 \pm 0^{\circ}$ & $5 \pm 0^{\mathrm{a}}$ & $1 \pm 0^{\text {a }}$ & 0 & 0 & 0 \\
\hline & IB & $4.7 \pm 0^{b}$ & $27 \pm 1^{2}$ & $18 \pm 2^{\prime \prime}$ & $64 \pm 6^{a}$ & $38 \pm 2^{2}$ & $7 \pm 2^{2}$ & $6 \pm 0^{\circ}$ & $5 \pm 0^{\circ}$ & $1 \pm 0^{\circ}$ & 0 & 0 & 0 \\
\hline & Sùt olum dō & nemi & & & & & & & & & & & \\
\hline & Kontrol & $5.8 \pm 0^{a}$ & $28 \pm 1^{\text {वे }}$ & $11 \pm 1^{\overline{3}}$ & $60 \pm 5^{\text {a }}$ & $30 \pm 3^{\circ}$ & $4 \pm 1^{\mathrm{a}}$ & $7 \pm 0^{\circ}$ & $4 \pm 0^{2}$ & $1 \pm 0^{a}$ & 0 & 0 & 0 \\
\hline & IA & $5.0 \pm 0^{6}$ & $29 \pm 3^{2}$ & $12+2^{\circ}$ & $61 \pm 4^{2}$ & $29 \pm 2^{\prime \prime}$ & $3 \pm 0^{2}$ & $6 \pm 0^{2}$ & $5 \pm 0^{\circ}$ & $1 \pm 0^{\circ}$ & 0 & 0 & 0 \\
\hline & IB & $5.1 \pm 0^{b}$ & $28 \pm 2^{a}$ & $12 \pm 1^{\circ}$ & $60 \pm 4^{2}$ & $30 \pm 2^{2}$ & $4 \pm 0^{a}$ & $7 \pm 0^{\circ}$ & $4 \pm 0^{2}$ & $1 \pm 0^{\circ}$ & 0 & 0 & 0 \\
\hline & Çiçekjenme & dönemi & & & & & & & & & & & \\
\hline \multirow[t]{8}{*}{4} & Kontrol & $5.1 \pm 0^{a}$ & $27 \pm 1^{\text {a }}$ & $9 \pm 2^{b}$ & $64 \pm 4^{2}$ & $38 \pm 3^{\prime \prime}$ & $7 \pm 1^{\circ}$ & $6 \pm 0^{2}$ & $6 \pm 0^{2}$ & $1 \pm 0^{\circ}$ & $1 \pm 0^{\circ}$ & 0 & 0 \\
\hline & IA & $4.6 \pm 0^{b}$ & $27 \pm 1^{\text {व }}$ & $12 \pm 1^{a}$ & $64 \pm 3^{2}$ & $37 \pm 3^{2}$ & $7 \pm 1^{a}$ & $6 \pm 0^{3}$ & $6 \pm 0^{2}$ & $2+0 "$ & $0^{a}$ & 0 & 0 \\
\hline & iB & $4.5 \pm 0^{\circ}$ & $27 \pm 1$. & $12 \pm 1$. & $63 \pm 5^{2}$ & $38 \pm 3^{4}$ & $7 \pm 1^{4}$ & $7 \pm 0^{\circ}$ & $5 \pm 0^{x}$ & $2+0^{2}$ & $0^{\circ}$ & 0 & 0 \\
\hline & Süt olum dő & nemi & & & & & & & & & & & \\
\hline & Kontrol & $5.4 \pm 0^{a}$ & $27 \pm 1^{\text {z }}$ & $6 \pm 1^{b}$ & $61 \pm 4^{2}$ & $31 \pm 2^{*}$ & $5 \pm 1^{\circ}$ & $6 \pm 0^{\circ}$ & $5 \pm 0^{\circ}$ & $1 \pm 0^{\circ}$ & $1 \pm 0^{\circ}$ & 0 & 0 \\
\hline & IA & $4.4 \pm 0^{\circ}$ & $28 \pm 3^{2}$ & $9 \pm 1$. & $61 \pm 5^{n}$ & $31 \pm 2^{3}$ & $5 \pm 0^{2}$ & $7 \pm 0^{\circ}$ & $4 \pm 0^{\circ}$ & $2 \pm 0^{\circ}$ & 0 & 0 & 0 \\
\hline & IB & $4.4 \pm 0^{\circ}$ & $28 \pm 1^{\text {a }}$ & $9 \pm 1^{\text {a }}$ & $61 \pm 6^{2}$ & $31 \pm 3^{2}$ & $4 \pm 1^{2}$ & $7 \pm 0^{\circ}$ & $5 \pm 0^{\prime \prime}$ & $2 \pm 0^{\circ}$ & $0^{\prime \prime}$ & 0 & 0 \\
\hline & Çiçeklenme & dönemi & & & & & & & & & & & \\
\hline \multirow[t]{8}{*}{7} & Kontrol & $5.1 \pm 0^{\mathrm{a}}$ & $28 \pm 1^{a}$ & $7 \pm 1^{b}$ & $64 \pm 3^{2}$ & $38 \pm 2^{3}$ & $7 \pm 2^{11}$ & $7 \pm 0^{\circ}$ & $5 \pm 0^{\circ}$ & $2 \pm 0^{b}$ & $1 \pm 0^{*}$ & 0 & $1 \pm 0^{8}$ \\
\hline & IA & $4.0 \pm 0^{b}$ & $27 \pm 2^{\text {a }}$ & $10 \pm 1=$ & $63 \pm 3^{2}$ & $38+2^{4}$ & $6 \pm 1^{*}$ & $6 \pm 0^{\circ}$ & $6 \pm 0^{\prime \prime}$ & $4 \pm 0^{\circ}$ & $0^{2}$ & 0 & $0^{\mathrm{a}}$ \\
\hline & IB & $4.1 \pm 0^{b}$ & $27 \pm 2^{\prime \prime}$ & $10 \pm 1^{2}$ & $62 \pm 6^{2}$ & $37 \pm 4^{4}$ & $6 \pm 2^{\circ}$ & $6 \pm 0^{\circ}$ & $5 \pm 0^{x}$ & $4 \pm 0^{2}$ & $0^{a}$ & 0 & $0^{\mathrm{a}}$ \\
\hline & Süt olum dö & nemi & & & & & & & & & & & \\
\hline & Kontrol & $5.1 \pm 0^{\mathrm{a}}$ & $28 \pm 2^{a}$ & $4 \pm 0^{b}$ & $60 \pm 4^{2}$ & $30 \pm 1^{*}$ & $4 \pm 1$ & $7 \pm 0^{\circ}$ & $4 \pm 0^{2}$ & $2 \pm 0^{\circ}$ & $1 \pm 0^{\circ}$ & 0 & $1 \pm 0^{\circ}$ \\
\hline & IA & $4.1 \pm 0^{b}$ & $28 \pm 2^{2}$ & $7 \pm 1^{\text {a }}$ & $60 \pm 4^{2}$ & $31 \pm 1^{\text {a }}$ & $3 \pm 1^{a}$ & $6 \pm 0^{2}$ & $4 \pm 0^{2}$ & $4 \pm 0^{2}$ & $0^{*}$ & 0 & $0^{a}$ \\
\hline & IB & $4.2 \pm 0^{6}$ & $29 \pm 3^{2}$ & $7 \pm 0^{\prime}$ & $59 \pm 4^{2}$ & $29 \pm 3^{2}$ & $3 \pm 1$ & $7 \pm 0^{\circ}$ & $5 \pm 0^{\circ}$ & $5 \pm 0^{3}$ & $0^{\prime \prime}$ & 0 & $0^{\text {a }}$ \\
\hline & Çiçeklenme & dönemi & & & & & & & & & & & \\
\hline \multirow[t]{8}{*}{15} & Kontrol & $5.0 \pm 0^{2}$ & $28 \pm 1^{2}$ & $6 \pm 1^{b}$ & $62 \pm 5^{2}$ & $38 \pm 2^{2}$ & $6 \pm 2^{a}$ & $6 \pm 0^{2}$ & $5 \pm 0^{2}$ & $4 \pm 1^{b}$ & $240^{3}$ & 0 & $3 \pm 1^{\circ}$ \\
\hline & iA & $3.7 \pm 0^{\circ}$ & $28 \pm 1^{2}$ & $10 \pm 1^{\circ}$ & $63 \pm 4^{2}$ & $38 \pm 2^{2}$ & $6 \pm 1^{2}$ & $7 \pm 0^{2}$ & $5 \pm 0^{2}$ & $6 \pm 0^{a}$ & $1 \pm 0^{3}$ & 0 & $2+0^{\circ}$ \\
\hline & iB & $3.9 \pm 0^{\circ}$ & $27 \pm 2^{\text {a }}$ & $10 \pm 1^{\mathrm{a}}$ & $62 \pm 4^{\circ}$ & $39 \pm 3^{\text {a }}$ & $6 \pm 1^{2}$ & $6 \pm 0^{2}$ & $4 \pm 0^{2}$ & $6 \pm 0^{a}$ & $1 \pm 0^{\circ}$ & 0 & $2+0^{3}$ \\
\hline & Süt olum dö & nemi & & & & & & & & & & & \\
\hline & Kontrol & $4.8 \pm 0^{2}$ & $27 \pm 2^{\text {a }}$ & $4 \pm 0^{6}$ & $59 \pm 3^{2}$ & $31 \pm 2^{2}$ & $5 \pm 1^{\circ}$ & $6 \pm 0^{\circ}$ & $4 \pm 0^{2}$ & $4 \pm 1^{b}$ & $2+0^{a}$ & 0 & $6 \pm 1^{\circ}$ \\
\hline & iA & $3.9 \pm 0^{b}$ & $26 \pm 2^{2}$ & $7 \pm 1^{a}$ & $59 \pm 3^{\prime \prime}$ & $30 \pm 1^{2}$ & $4 \pm 1^{2}$ & $6 \pm 0^{\prime \prime}$ & $4 \pm 0^{a}$ & $7 \pm 0^{2}$ & $1 \pm 0^{\circ}$ & 0 & $5 \pm 1^{\prime \prime}$ \\
\hline & iB & $3.9 \pm 0^{\circ}$ & $26 \pm 2^{a}$ & $7 \pm 1^{\circ}$ & $58 \pm 3^{\prime \prime}$ & $29 \pm 2^{a}$ & $4 \pm 1^{\circ}$ & $7 \pm 0^{2}$ & $5 \pm 0^{\prime}$ & $6 \pm 0^{\prime \prime}$ & $1 \pm 0^{2}$ & 0 & $5 \pm 1^{2}$ \\
\hline & Çiçeklenme & donemi & & & & & & & & & & & \\
\hline \multirow[t]{7}{*}{60} & Kontrol & $4.9 \pm 0^{\mathrm{a}}$ & $26 \pm 1^{a}$ & $6 \pm 1^{\circ}$ & $63 \pm 3^{\circ}$ & $39 \pm 1^{2}$ & $6 \pm 1^{2}$ & $6 \pm 0^{\circ}$ & $5 \pm 0^{2}$ & $4 \pm 0^{b}$ & $3 \pm 0^{*}$ & $2+0^{3}$ & $5 \pm 0^{\prime \prime}$ \\
\hline & IA & $3.7 \pm 0^{\circ}$ & $27 \pm 2^{2}$ & $10 \pm 2^{2}$ & $63 \pm 3^{\circ}$ & $39 \pm 1^{\circ}$ & $7 \pm 0^{3}$ & $6 \pm 0^{2}$ & $5 \pm 0^{2}$ & $6 \pm 0^{2}$ & $1 \pm 0^{b}$ & $0^{b}$ & $5 \pm 0^{3}$ \\
\hline & IB & $3.8 \pm 0^{\circ}$ & $26 \pm 2^{11}$ & $9 \pm 2^{\circ}$ & $62 \pm 4^{a}$ & $38 \pm 3^{\circ}$ & $6 \pm 0^{\circ}$ & $6 \pm 0^{\circ}$ & $5 \pm 0^{a}$ & $6 \pm 0^{2}$ & $1 \pm 0^{b}$ & $0^{6}$ & $4 \pm 0^{a}$ \\
\hline & Süt olum dỏ & nemi & & & & & & & & & & & \\
\hline & Kontrol & $4.5 \pm 0^{\mathrm{a}}$ & $28 \pm 2^{\prime \prime}$ & $4 \pm 0^{6}$ & $59 \pm 3^{\circ}$ & $30 \pm 2^{\circ}$ & $4 \pm 1^{2}$ & $7 \pm 0^{2}$ & $4 \pm 0^{a}$ & $5 \pm 0^{6}$ & $3 \pm 1^{\text {a }}$ & $2 \pm 0^{a}$ & $9 \pm 1^{2}$ \\
\hline & IA & $3.8 \pm 0^{b}$ & $27 \pm 2^{a}$ & $6 \pm 1^{\text {a }}$ & $59 \pm 2^{\text {" }}$ & $30 \pm 3^{2}$ & $4 \pm 1$ a & $7 \pm 0^{\circ}$ & $5 \pm 0^{\prime \prime}$ & $8 \pm 0^{\circ}$ & $1 \pm 0^{6}$ & $0^{b}$ & $9 \pm 1^{\text {" }}$ \\
\hline & IB & $3.8 \pm 0^{b}$ & $27 \pm 1^{2}$ & $6 \pm 1$ " & $58 \pm 4^{2}$ & $29 \pm 2^{z}$ & $4 \pm 1^{3}$ & $7 \pm 0^{2}$ & $5 \pm 0^{\circ}$ & $8 \pm 0^{\circ}$ & $1 \pm 0^{b}$ & $0^{b}$ & $9 \pm 1$ " \\
\hline
\end{tabular}

KM, kuru madde; SEK, suda eriyebilir karbonhidrat; NDF, nötr deterjanda çözönmeyen lif; $A D F$, asit deterjanda çözünmeyen lif; $A D L$, asit deterjanda çözünmeyen lignin; $H K$, ham kül; HP, ham protein; LA, laktik asit; AA, asetik asit; $B A$, bütrik asit; $I_{i}$ inokulant $A$; IB, inokulant B.

Aynı satırda farkı harfler ile gösterilen ortalamalar arasındaki farkılıklar önemlidir $(P<0.05)$.

- Hasattan hemen sonra alınan ve araştırmanın başlangıç materyalini oluşturan taze sorgumlara ait kimyasal analiz sonuçiarı bilgi amacı ile verilmiş olup, istatistik analizlerin dışında tutuimuşlardır.

Taze ve silolanmış sorgumlara ait mikrobiyolojik analiz sonuçiarı Çizelge 2' de verilmiş̧tir. Çizelge 2 ' de de görüldağü gibi araştırmada kullanılan her iki bakteriyal inokulant da fermantasyonun 4. gününden itibaren sorgum silajlarınin lactobacilli içeriklerini önemli düzeyde artırmıştı $(\mathrm{P}<0,05)$. Her iki inokulant da sorgumda silaj fermantasyonu için yeterli düzeyde bulunan SEK' I kullanıp, lactobacilli gelișimini hizlandirarak bu tôr bakterilerin silajlardaki dúzeyinini artırmışlardır. Bunun yanı sira tum silajlarda fermantasyon başlangıcından itibaren önemsiz düzeyde maya saptanırken, fermantasyonun son gününde de (60. gün) önemsiz düzeyde clostridia saptanmıştir. Diğer yandan inokulant kullanılan silajlarda fermantasyonun hiçbir döneminde küf ve enterobacteria gibi mikroorganizmalara rastlanmazken, kontrol gruplarında fermantasyonun 7 . gününden itibaren ônemli 
dũzeyde küf bulunmuştur $(P<0.05)$ Dolayısıyla araştırmada kullanılan her iki inokulant da silajlarda küf oluşumunu engellerken, silajların maya, enterobacteria ve clostridia içerikleri üzerinde önemli bir etkide bulunmamıştır. Tüm silajlarda görülen maya aktivitesi sonucunda silajlarda bir fermantasyon ürünü olarak etanol oluşmuştur (Çizelge 1). Ancak sonuç olarak yine de, bu araştırmadaki sorgum silajlarında görülen ve silaj fermantasyonu üzerinde olumsuz etkileri bulunan mikroorganizmaların düzeylerinin oldukça dūşük olduğu söylenebilir. Bu konu ile ilgili olarak araştırmadan elde edilen bulgular, benzer konularda yapilan araștırma bulguları ile uyum göstermektedir (Meeske ve ark., 1993; Weinberg ve ark., 1993 b).

Araştırmanın son gününde (60. gün) açılan silajlar 5 gũn süre ile aerobik stabilite testine tabi tutulmuş ve bu testin sonuçları Çizelge $3^{\prime}$ de verilmiștir.

Çizelge 2. Sorgum silajlarına ait mikrobiyolojik analiz sonuçları $\left(\bar{x} \pm \mathrm{S} \bar{x} ; \log \mathrm{cfu}^{-1} \mathrm{KM}\right)$

\begin{tabular}{|c|c|c|c|c|c|c|}
\hline Günler & Uygulama & Lactobacilli & Maya & Küf & Enterobacteria & Clostridia \\
\hline & Taze $^{*}$ & & & & & \\
\hline \multirow[t]{2}{*}{0} & Çiçeklenme dönemi & $4.3 \pm 0.41$ & $4.5 \pm 0.35$ & $3.0 \pm 0.50$ & $2.7 \pm 0.38$ & 0 \\
\hline & $\begin{array}{l}\text { Sût olum dönemi } \\
\text { Çiçeklenme dönemi }\end{array}$ & $4.4 \pm 0.42$ & $5.3 \pm 0.61$ & $4.3 \pm 0.39$ & $4.6 \pm 0.84$ & 0 \\
\hline \multirow[t]{8}{*}{2} & Kontrol & $4.5 \pm 0.50^{a}$ & $4.5 \pm 0.54^{a}$ & 0 & 0 & 0 \\
\hline & IA & $5.3 \pm 0.52^{a}$ & $4.2 \pm 0.41^{\mathrm{a}}$ & 0 & 0 & 0 \\
\hline & IB & $5.2 \pm 0.45^{a}$ & $4.1 \pm 0.63^{a}$ & 0 & 0 & 0 \\
\hline & Süt olum dönemi & & & & & \\
\hline & Kontrol & $4.6 \pm 043^{a}$ & $5.9 \pm 0.46^{\mathrm{a}}$ & 0 & 0 & 0 \\
\hline & IA & $5.3 \pm 0.47^{a}$ & $5.8 \pm 0.54^{a}$ & 0 & 0 & 0 \\
\hline & IB & $5.3 \pm 0.43^{a}$ & $5.7 \pm 0.49^{\mathrm{a}}$ & 0 & 0 & 0 \\
\hline & Çiçeklenme dönemi & & & & & \\
\hline \multirow[t]{8}{*}{4} & Kontrol & $4.7 \pm 0.36^{b}$ & $4.2 \pm 0.59^{a}$ & 0 & 0 & 0 \\
\hline & IA & $5.9 \pm 0.47^{a}$ & $4.3 \pm 0.46^{a}$ & 0 & 0 & 0 \\
\hline & IB & $5.9 \pm 0.45^{a}$ & $4.2 \pm 0.51^{\mathrm{a}}$ & 0 & 0 & 0 \\
\hline & Süt olum dönemi & & & & & \\
\hline & Kontrol & $5.1 \pm 0.44^{b}$ & $6.2+0.57^{a}$ & 0 & 0 & 0 \\
\hline & IA & $6.4 \pm 0.56^{a}$ & $6.5 \pm 0.48^{a}$ & 0 & 0 & 0 \\
\hline & IB & $6.4 \pm 0.41^{a}$ & $5.9 \pm 0.35^{a}$ & 0 & 0 & 0 \\
\hline & Çiçeklenme dönemi & & & & & \\
\hline \multirow[t]{8}{*}{7} & Kontrol & $5.0 \pm 0.41^{b}$ & $6.1 \pm 0.63^{a}$ & $2.8 \pm 0.40^{\mathrm{a}}$ & 0 & 0 \\
\hline & IA & $6.3 \pm 0.43^{a}$ & $4.0 \pm 0.33^{\mathrm{a}}$ & $0^{6}$ & 0 & 0 \\
\hline & IB & $6.2 \pm 0.36^{a}$ & $4.1 \pm 0.37^{a}$ & $0^{b}$ & 0 & 0 \\
\hline & Süt olum dönemi & & & & & \\
\hline & Kontrol & $5.4 \pm 0.48^{b}$ & $5.9 \pm 0.55^{a}$ & $2.4 \pm 0.36^{2}$ & 0 & 0 \\
\hline & IA & $7.4 \pm 0.39^{a}$ & $6.2 \pm 0.43^{a}$ & $0^{b}$ & 0 & 0 \\
\hline & IB & $7.0 \pm 0.55^{a}$ & $6.1 \pm 0.50^{\mathrm{a}}$ & $0^{b}$ & 0 & 0 \\
\hline & Çiçeklenme dönemi & & & & & \\
\hline \multirow[t]{8}{*}{15} & Kontrol & $5.3 \pm 0.47^{b}$ & $3.6 \pm 0.39^{a}$ & $3.1 \pm 0.44^{a}$ & 0 & 0 \\
\hline & IA & $7.6 \pm 0.40^{a}$ & $4.2 \pm 0.41^{\mathrm{a}}$ & $0^{6}$ & 0 & 0 \\
\hline & iB & $7.7 \pm 0.59^{a}$ & $4.2+0.44^{\prime \prime}$ & $0^{b}$ & 0 & 0 \\
\hline & Süt olum dönemi & & & & & \\
\hline & Kontrol & $6.6 \pm 0.53^{b}$ & $6.3 \pm 0.46^{a}$ & $2.6 \pm 0.31^{\mathrm{a}}$ & 0 & 0 \\
\hline & IA & $8.5 \pm 0.46^{a}$ & $6.8 \pm 0.60^{\prime \prime}$ & $0^{b}$ & 0 & 0 \\
\hline & iB & $8.3 \pm 0.44^{a}$ & $6.7 \pm 0.44^{\mathrm{a}}$ & $0^{b}$ & 0 & 0 \\
\hline & Çiçeklenme dönemi & & & & & \\
\hline \multirow{7}{*}{60} & Kontrol & $6.8 \pm 0.63^{b}$ & $2.9 \pm 0.45^{a}$ & $3.4 \pm 0.36^{a}$ & $0.2 \pm 0^{\pi}$ & $1.4 \pm 0.04^{\mathrm{a}}$ \\
\hline & IA & $8.4 \pm 0.90^{a}$ & $3.6 \pm 0.39^{\mathrm{a}}$ & $0^{b}$ & $0^{2}$ & $2.1 \pm 0.07^{a}$ \\
\hline & IB & $8.6 \pm 0.77^{a}$ & $3.3 \pm 0.28^{a}$ & $0^{b}$ & $0^{a}$ & $1.8 \pm 0.12^{a}$ \\
\hline & Süt olum dönemi & & & & & \\
\hline & Kontrol & $7.7 \pm 0.76^{b}$ & $7.6 \pm 0.58^{\mathrm{a}}$ & $2.1 \pm 0.26^{a}$ & $0.4 \pm 0^{a}$ & $3.5 \pm 0.14^{a}$ \\
\hline & IA & $9.5 \pm 0.67^{a}$ & $7.1 \pm 0.32^{a}$ & $0^{b}$ & $0^{\mathrm{a}}$ & $3.3 \pm 0.09^{\mathrm{a}}$ \\
\hline & IB & $9.2 \pm 0.71^{a}$ & $7.8 \pm 0.41^{\mathrm{a}}$ & $0^{b}$ & $0^{a}$ & $4.0 \pm 0.10^{a}$ \\
\hline
\end{tabular}

Log cfu, logaritma koloniform ünite; KM, kuru madde; IA, inokulant A; Inokulant B.

Aynı sütunda farklı harfler ile gösterilen ortalamalar arasındaki farklılıklar önemlidir ( $P<0.05)$.

* Hasattan hemen sonra alınan ve araştırmanın bașlangıç materyalini oluşturan taze sorgumlara ait kimyasal analiz sonuçları bilgi amacı ile verilmiş olup, istatistik analizlerin dișında tutulmuşlardır. 
Çizelge 3. Silajların aerobik stabilite testi sonuçları $(\bar{x} \pm S \vec{x})$

\begin{tabular}{lcccc}
\hline Uygulama & $\mathrm{pH}$ & $\mathrm{CO}_{2}$ & Maya* & Kuff $^{*}$ \\
\hline $\begin{array}{l}\text { Cliçeklenme dönemi } \\
\text { Kontrol }\end{array}$ & $4.9 \pm 0.43^{\mathrm{a}}$ & $1.4 \pm 0.12^{\mathrm{a}}$ & $3.9 \pm 0.36^{\mathrm{a}}$ & $9.3 \pm 1.61^{\mathrm{a}}$ \\
IA & $3.9 \pm 0.35^{\mathrm{b}}$ & $1.7 \pm 0.10^{\mathrm{a}}$ & $4.3 \pm 0.41^{\mathrm{a}}$ & $6.4 \pm 1.30^{\mathrm{b}}$ \\
IB & $3.9 \pm 0.40^{\mathrm{b}}$ & $1.5 \pm 0.14^{\mathrm{a}}$ & $4.4 \pm 0.28^{\mathrm{a}}$ & $6.0 \pm 1.24^{\mathrm{b}}$ \\
Süt olum dönemi & $4.6 \pm 0.38^{\mathrm{a}}$ & $5.1 \pm 0.10^{\mathrm{a}}$ & $4.6 \pm 0.55^{\mathrm{a}}$ & $12.0 \pm 1.88^{\mathrm{a}}$ \\
Kontrol & $4.0 \pm 0.41^{\mathrm{b}}$ & $4.7 \pm 0.13^{\mathrm{a}}$ & $4.2 \pm 0.46^{\mathrm{a}}$ & $9.0 \pm 1.29^{\mathrm{b}}$ \\
IA & $3.9 \pm 0.33^{\mathrm{b}}$ & $5.5 \pm 0.15^{\mathrm{a}}$ & $4.9 \pm 0.40^{\mathrm{a}}$ & $8.7 \pm 1.13^{\mathrm{b}}$ \\
IB & &
\end{tabular}

$\mathrm{CO}_{2}$, karbondioksit $\left(\mathrm{g} \mathrm{kg}^{-1} \mathrm{KM}\right)$; $\mathrm{IA}$, inokulant $\mathrm{A}$; $\mathrm{iB}$, inokulant $\mathrm{B}$.

"Maya ve küf log cfu $\mathrm{g}^{-1} \mathrm{KM}$ olarak verilmiştir.

Aynı sütunda farklı harfler ile gösterilen ortalamalar arasındaki farkilıklar önemlídir $(P<0.05)$.

Çizelge $3^{i}$ de de göraldüğá gibi, inokulantların sorgum silajlarının aerobik stabiliteleri üzerinde etkileri onnemsiz bulunmuştur. Kontrol grupları da dahil olmak azere tăm silajlarda $\mathrm{CO}_{2}$ üretimi görülmüștür. Özellikle bu dönemde silajlarda görälen maya populasyonu silajların aerobik stabiliteleri uzerinde olumsuz etkide bulunmuş ve silajlarda $\mathrm{CO}_{2}$ aretimine yol açmıştır. Nitekim Seale (1986) silajlarda görülen $\mathrm{CO}_{2}$ üretiminin başlıca nedeninin mayalar olduğunu bildirmiştir. Ayrıca silajlarda bozulmanın olduğu bu 5 günläk dönem içerisinde silajların pH' larında az miktarda bir artış górülmüştâr. Her iki inokulant da bu dönemde silajların küf içeriğini onemli düzeyde azaltmıştır $(P<0,05)$. Ciçekienme dönemindeki sorgum silajlarında görulen $\mathrm{CO}_{2}$ uretimi, süt olum dönemindeki sorgum silajlarında göralen $\mathrm{CO}_{2}$ oretiminden daha az olmuștur. Dolayısıyla çiçeklenme döneminde yapilan silajlardaki bozulma süt olum döneminde yapilan silajlara göre daha az dôzeyde olmuștur. Bunun sonucunda sât olum dönemindeki silajların aerobik stabiliteleri çiçeklenme dönemindeki silajların aerobik stabilitelerine göre daha yetersiz düzeyde kalmıştır. Bu duruma lactobacilli içerikleri daha fazla olan süt olum dönemindeki silajlarda görülen yüksek düzeydeki laktik asit üretiminin yol açtığı düşûnülmektedir. Çünkü burada oluşan laktatlar, laktatları besin maddesi olarak kullanan mayalar tarafından tâketilmiş ve bu da silajlarda daha fazla bozulmaya neden olarak sut olum dönemindeki silajların aerobik stabilitelerini düşūrmüştūr. Silajların aerobik stabiliteleri ile ilgili olarak araştırmadan elde edilen bulgular, benzer konulardaki araştırma bulguları ile de uyum göstermektedir (Kennedy, 1990; Weinberg ve ark. 1993 a,b; Meeske ve ark., 1993; Filya ve ark., 1999; Filya ve ark., 2000).

Sorgum silajlarının 48 saatlik inkábasyon sonucundaki rumen parçalanabilirlik özellikleri ile ilgili olarak araştırmadan elde edilen bulgular Çizelge $4^{\prime}$ de verilmiştir.

Çizelge 4' de de görüldüguu gibi, her iki inokulantın da silajların KM ve organik madde (OM) parçalanabilirlikleri azerinde etkileri őnemsiz düzeyde bulunmuştur. Bunun da başlıca nedeni sorgumun yeterli düzeyde SEK içermesidir. Ancak özellikle LAB' nin yani sira sellalaz ve hemisellülaz gibi bitki hücre duvarını parçalayıcı enzimler de içeren inokulant $\mathrm{B}$, silajların KM ve OM parçalanabilirliklerini diğer gruplara göre önemsiz de olsa bir miktar artırmıştır. Diğer yandan araştırmada sŭt olum dönemindeki sorgum silajlarının KM ve OM parçalanabilirliklerinin çiçeklenme dönemindeki sorgum silajlarınınkinden daha yüksek olduğu saptanmiştır.

Çizeige 4. Silajlarinin rumen parçalanabilirlik özellikleri ( $\bar{x} \pm S \bar{x}, \%)$

\begin{tabular}{lll}
\hline Uygulama & KM parçalanabilirliği & OM parçalanabiliriliği \\
\hline $\begin{array}{c}\text { Çiçeklenme dönemi } \\
\text { Kontrol }\end{array}$ & $56.26 \pm 2.35^{\mathrm{a}}$ & $57.15 \pm 2.46^{\mathrm{a}}$ \\
IA & $56.41 \pm 2.72^{\mathrm{a}}$ & $57.45 \pm 1.97^{\mathrm{a}}$ \\
IB & $57.00 \pm 1.54^{\mathrm{a}}$ & $57.94 \pm 2.59^{\mathrm{a}}$ \\
Sut olum dönemi & $61.48 \pm 1.85^{\mathrm{a}}$ & $62.18 \pm 1.35^{\mathrm{a}}$ \\
Kontrol & $61.78 \pm 2.43^{\mathrm{*}}$ & $62.36 \pm 1.70^{\mathrm{a}}$ \\
IA & $62.39 \pm 1.97^{\mathrm{a}}$ & $62.75 \pm 2.31^{\mathrm{*}}$ \\
\hline
\end{tabular}

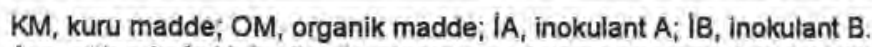

Aynı sütunda farklı harfler ile gösterilen ortalamalar arasındaki farklılıklar önemlidir $(P<0.05)$. 
Oysa genel olarak sorgum bitkisinin olgunlaşmasıyla birlikte sindirilebilirliği dașmektedir. Nitekim bu olgu çeșitli çalışmalarda gósterilmiştir (Fox ve ark., 1970; Black ve ark., 1980; Donnhauser ve ark., 1990). Bu olgu ózellikle ot tipi sorgum çeşitleri için doğru olup, bitkinin olgunlaşmaya başlamasiyla birlikte bitkinin höcre duvarı kapsamı artmaktadir. Ancak dane verimi yüksek çeșitlerde bitkinin dane bağlamasiyla ve danelerin olgunlaşmasıyla birlikte bitkinin nişasta içeriği artmakta ve oransal olarak hücre duvan kapsamı duşmektedir. Bu trend bu çalıșmada da görolmüștür. Silajların KM ve OM parçalanabilirlikleri lie ilgili olarak araştirmadan elde edilen bulgular benzer konularda yapilan çeşitli araștırma buiguları lle uyum göstermektedir (Owen ve Webster, 1963; Danley ve Vetter, 1973; Hart, 1990; Meeske ve ark., 1993).

\section{Sonuç}

Çiçeklenme ve süt olum donemlerinde hasat edilerek silolanan sorgum bitkisinde silaj katkı maddesi olarak kullanilan bakteriyal inokulantlar, silajlann fermantasyon ozellikierini olumlu yönde etkilemişlerdir. Diğer yandan araștırmada kullanılan her iki inokulant da silajların aerobik stabilitelerini etkilemerniştir. Ancak bitkilerin olgunlaşmaya başlamasıyla birlikte aerobik stabiliteleri doşmuş̧or, Inokulantiar silajlarin rumen $K M$ ve $O M$ parçalanabilirliklerini de etkilememişlerdir. Inokulant $B$, LAB' nin yani sira sellalaz ve hemisellulaz gibi hocre duvarını parçalayıcı enzimler de içermesine rağmen, sorgum silajlarinin höcre duvarı kapsamim azaltacak yönde bir etkide bulunmamiştır. Sorgumun silaj fermantasyonu açısindan yeterli düzeyde SEK içermesinden dolay, inokulant $B^{\prime}$ nin höre duvarinı parçalayıcı etkisinin sorgum silajları uzerinde cok belirgin olarak ortaya çıkmağı düșünulmektedir. Soz konusu inokulantın bu etkilerinin ozellikle SEK içeriği yetersiz olan bitkilerde daha belirgin olarak ortaya çıabileceği soylenebilir. Araştırmadan elde edilen bulguların genel olarak değerlendirilmesi halinde, biyolojik bir silaj katkı maddesi olan bakteriyal inokulantlarin silaj fermantasyonu. aerobik stabilite ve ruminantlardaki değerlendirilme ddzeylerinin belirlenmesi amacıyla daha çok sayıda bilimsel araştırmaya gereksinim duyulduogu açıktır.

\section{Kaynaklar}

Akyildiz, A. R. 1984. Yemler Bilgisi Laboratuvar Kılavuzu, Anikara Univ. Zir Fak. Yay, 895, Uygulama Kilavuzu No: 213. Ankara, $236 \mathrm{~s}$

Anonim, 1983. Gida Maddelen Muayene ve Analiz Yountemleri. T. O.K.B. Gida Işleri Gen. Müd. Yay, 65, Ankara, 796s.

Ashbell, G., Z. G. Weinberg, A. Azriell, $Y$. Hen and B. Horev, 1991. A simple system to study the aerobic deterioration of silages, Can. Agric. Eng., 33: 391-393.

Black, J, R., L. O. Ely, M. E. McCullough and E. M. Sudweeks 1980. Effect of stage of maturity and silage additives upon the yield of gross and digestible energy in sorghum silage. J. Anim. Sci, 50: 617-624.
Bolsen, K. K., R. N. Sonon, B. Dalke, R. Pope, J. G. Rlley and A. Laytimi, 1992a. Evaluation of inoeulant and NPN silage additives: A Summary of 26 Triais and 65 Farm- Scale Silages. In: Kansas Agric, Exp. Sta. Rpt. of Prog. 651 Kansas State University, Manhattan. pp. $101-102$

Bolsen, K. K, D.G. Tiemann, R.N Sonon, A. Hart, B. Dalke, I. T Dickerson and C, Lin, 1992b. Evaluation of inoculanttreated corn silages, in Kansas State University Manhattan. pp. 103- 906.

Danley, M. M. and R. L. Vetter, 1973. Changes in carbohydrate and nitrogen fractions and digestibility of forages: maturity and ensiling. J. Anim. Sci, 37; 994999.

Devies, O. D. and P A, Hall, 1999. The effect of applying an inoculant containing $L$. buchneri to high dry matter ryegrass swards ensiled in wrapped, round bales. In: Proc, $12^{\text {th }}$ International Silage Conference. Uppsala, Sweden. pp. 262-263.

Donnhauser, C. S., R. H. Drewes, E, A, Van Zyl and C, J Van Rooyen, 1990. The production of different forage sorghum and babala cultivars in the Western Transvaal. d. Grasst. Soc. S. Afr., 7:179-183.

Dubois, M., K. A. Giles, J. K. Harmilton, P. A. Rebes and F. Smith 1956. Colorimetric method for determination of sugars and related substances. Anal. Chem., 28: 350-356.

Fllya, I., G. Ashbell, Z. G. Weinberg and Y. Hen, 1999, The effect of applying lactic acid bacterial inoculants at ensiling on the fermentation and aeroblc stability of whole crop wheat sllage. In: Proc: $12^{\text {th }}$ International Silage Conference. Uppsala, Sweden. pp. 268-269.

Filya, I., 2000a. Silaj Fermantasyonu. Alalürk Ũriv. Zir. Fak. Derg., Erzurum (Basinda).

Filya, 1, 2000b. Bazı silaj katkı maddelerinin ruminantlann performansları Uzzerindeki etkileri. Ege Zootekni Demeği Hayvansal Öretim Dergisi Izmir (Basımda).

Filya, I. G. Ashbell, Y. Hen and Z. G. Weinberg, 2000. The effect of bacterial inoculants on the fermentation and aerobic stability of whole crop wheat silage. Anim. Feed Sci. and Technol. 88: 39-46.

Fox, D. G., E. W. Kosterman, H. W. Newland and R. R. Johnsoon, 1970. Net energy of corn and grain resistant grain sorghium rations for steers when fed as grain or silage. J, Anim. Sci. 30: $303-308$,

Goto, M., A. H. Gordon and A. Chesson, 1991. Changes in cellwall composition and degradability of sorghum during growth and maturation. J. Sci. Food Agric., 54: 47-60

Harrison, J. H. 1989. Use of silage additives and their effect on animal productivity. In: Proc. of the Pacific Northwest Animal Nutrition Conference. Boise, Idaho. pp. 27-35.

Hart, S. P 1990, Effects of altering the grain content of sorghum on its nutritive value. J. Anim. Sci. 68: 3832-3842.

Henderson, A. R., D. R. Seale, D, H. Anderson and S. J. E. Heron, 1990. The effect of formic acid and bacterial inoculants on the fermentation and nutritlve value of perennial ryegrass silages. In: $\mathbf{S}$. Lindgren and $K$. $L$. Petterson (Editors). Proc. of the Eurobac Conference, Swedish University of Agricultural Sciences, Uppsala, Sweden. pp. 93-98. 
Holzer, M., E. Mayrhuber, H. Danner, L. Madzingaidzo and R. Braun, 1999. Effect of Lactobacillus $S P$ and Enterococcus sp on ensilaging aerobic stability. In: Proc. $12^{\text {th }}$ International Silage Conference. Uppsala, Sweden. pp. 270-271.

Kennedy, S. J. 1990. Evaluation of the three bacteria inoculants and formic acid as additives for first harvest grass. Grass Forage Sci., 45; 153-165.

Lindgren, S., P. Lingvall, A. Kartzow and E. Rydberg, 1983. Effects of inoculants, grain and formic acid on silage fermentation. Swedish J. Agric. Res. 13; 91-100.

McDonald, P., A. R. Henderson and S. J. E. Heron, 1991 Microorganisms, In: P. McDonald, A.R. Henderson and S.J.E Heron (Editors), The Biochemistry of Silage, $2^{\text {n }}$ edn., Aberystwyth: Chalcombe Publications. pp. 81-152.

Meeske, R., G. Ashbell, Z.G. Weinberg and T. Kipnis, 1993 Ensiling forage sorghum at two stages of maturity with the addition of lactic acid bacterial inoculants. Anim. Feed Sci, and Technol., 43: 165-175.

Mehrez, A. Z, and E. R. Ørskov, 1977. A study of the artificial fibre bag technique for determining the digestibility of feeds in the rumen. J. Agric. Sci. (Cambridge) $88,645-$ 650.

Muck, R. E. 1993. The role of silage additives in making high quality silage. In: Proc. Nat. Silage Prod. Conf. NRAES67, Ithaca, New York. pp. 106-116.

Ohyama, Y., T. Morichi and S. Masahi, 1975. The effect of inoculation with Lactobacillus Plantarum and the addition of glucose at ensiling on the quality of aerated silages. J. Sci. Food Agric., 26: 1001-1008.

Ørskov, E.R and I. MCDonald, 1979. The estimation of protein degradability in the rumen from incubation measurements weighed according to rate of passage. J. Agric. Sci. (Cambridge), 92: 499-503.

Owen, F. G. and O. J. Webster, 1963. Effect of sorghum maturity at harvest and variety on certain chemical constituents in sorghum silages. Agron. J., 55: 167-169.
Pahlow, G. 1982. Verbesserung der aeroben stabilitat von silagen durc impfpraparate. Das Wirtschaftseigene Futter 28: $107-122$.

Rooke, J. A, and F. Kafilzadeh, 1994. The effect upon fermentation and nutritive value of silages produced after treatment by three different inoculants of lactic acid bacteria applied alone or in combination. Grass Forage Sci., 49: 324-333.

SAS., 1988. Statistical Analysis System @. User's Guide: Statistics, Version 6 Edition. SAS Inst., Inc., Cary, NC.

Seale, D. R. 1986. Bacterial inoculants as silage additives. J. Appl. Bacteriol. 61 (Suppl.), 9S-26S.

Spoelstra, S. F. 1984. Some Methods to Evaluate the Role of Clostridia in Silage. Internal Report No: 168, Institute for Livestock Feeding and Nutrition Research, Lelystad, The Netherlands.

Van Soest, P. J. 1982. Analytical systems for evaluation of feeds. In: P. J. Van Soest (Editor), Nutritional Ecology of the Ruminant. Cornell University Press, Ithaca, NY, Chapter 6, pp. 75-94.

Weinberg, Z. G. G., Ashbell and A. Azrieli, 1988. The effect of applying lactic acid bacteria at ensilage on the chemical and microbiological composition of vetch, wheat, and alfalfa silages. J. Appl. Bacteriol. 64: 1-7.

Weinberg, Z. G., G. Ashbell and A. Azrieli and I. Brukental, 1993a. Ensiling peas, ryegrass, and wheat with additives of lactic acid bacteria (LAB) and cell wall degrading enzymes. Grass Forage Sci., 48: 70-78.

Weinberg, Z. G., G. Ashbell, Y. Hen and A. Azrieli, 1993b. The effect of applying lactic acid bacteria ensiling on the aerobic stability of silages. J. Appl. Bacteriol., 75: 512 518.

Woolford, M. K. 1984. The chemistry of silage In. M. K Woolford (Editor), The Silage Fermentation. Marcel Dekker, Inc., New York, pp. 71-132. 